\title{
An Opportunity for Conversion: American Jesuits and the Response to Laudato si'
}

\author{
Ken Homan, S.J. \\ Marquette University High School, Milwaukee \\ kenhomansj@gmail.com
}

\begin{abstract}
In May 2015, Pope Francis published Laudato si', and since then Jesuits throughout the world are seeking to respond to the encyclical. In the United States, however, much of the responses came from the twenty-eight Jesuit colleges and universities. Despite these efforts, tremendous work and challenges await the Jesuits communities in the United States. This essay describes and evaluates the American Jesuits' efforts prior to and in response to Pope Francis's call for an integral ecology. Furthermore, it recommends an integral ecology examen to help the Society of Jesus move from comfortable participation in injustice to hope-filled missionary vigor.
\end{abstract}

\section{Keywords}

Laudato si' - poverty - environment - covenant - justice - education - ecological conversion - Ignatian spirituality - examen

* Ken Homan, S.J. is a brother from the Wisconsin Province. He grew up in St. Louis, Missouri, completing his education at four Jesuit institutions. Presently, he serves as a high school theology teacher and wrestling coach at Marquette University High School. His interest in environmental stewardship began in high school where he worked on river maintenance and flourished through hiking and camping. Ken also worked for the national parks and national forests where he educated on connections between humanity, history, and the natural world. Ken mainly focuses on the relationships between the poor and environmental justice. 


\section{Introduction}

\section{Challenges exist to be overcome! \\ Let us be realists, but without losing our joy, \\ our boldness and our hope-filled commitment. \\ Let us not allow ourselves to be robbed of missionary vigor!!}

This past summer, Pope Francis published Laudato si'-a beautiful, challenging, and welcome interpretation of Catholic doctrine - an encyclical that identifies many of the environmental injustices that the world presently confronts. Yet, as the pope stated in Evangelii gaudium, "Challenges exist to be overcome!"2 The challenges, as well as the sorrows and hopes, which Pope Francis describes, emerge from an integral approach to ecology. ${ }^{3}$ Integral ecology points not just to stewardship of the earth; rather, as elaborated by Pope Francis, such an approach recognizes the binding relationship between God, the person, humanity at large, and the natural world into a covenant. ${ }^{4} \mathrm{~A}$ sin against one party in the relationship always affects the others. Likewise, healing the relationship with one party and building a more just world equally heals that relationship with the other parties. ${ }^{5}$ Thus, an integral ecology simultaneously listens to the cry of the poor, the cry of creation, and God's cry for humanity.

1 Francis, Evangelii gaudium [Apostolic Exhortation on the Proclamation of the Gospel in Today's World], November 24, 2013, n. 109, http://www.vatican.va/holy_father/francesco/ apost_exhortations/documents/papa-francesco_esortazione-ap_20131124_evangelii-gaudi um_en.html (accessed June 10, 2016).

2 Ibid.

3 Pope Francis used "integral ecology" frequently in Laudato si', and likewise it is a significant term in this article.

4 Francis, Laudato si', n. 210. Although Pope Francis does not explicitly develop his theological notion of covenant, he nevertheless implicitly names it as efforts to "restore the various levels of ecological equilibrium, establishing harmony within ourselves, with others, with nature and other living creatures, and with God." For more on an ecological covenant, see Wesley Granberg-Michaelson, "Covenant and Creation," in Liberating Life: Contemporary Approaches to Ecological Theology, eds. Charles Birch, William R. Eakin, Jay B. McDaniel, pp. 27-36 (Maryknoll, NY: Orbis Books 1990).

5 Raymond Edward Brown, Joseph A. Fitzmyer, and Roland E. Murphy, eds., The New Jerome Biblical Commentary (Englewood Cliffs, NJ: Prentice-Hall, 1990), para. 77:82. The New Jerome Biblical Commentary notes that pre-Monarchy, the twelve tribes of Israel were responsible for maintaining peace with each other and God. Moreover, in 77:85, it is noted that Jeremiah addresses the covenant as part of the individual relationship with God. In Genesis 1:28-31, God establishes a covenant with Adam (thus all creation) that includes stewardship of the environment. Humanity then becomes partners (though lesser) with God in care for that creation, including it in the covenant. Humans continue their covenantal relationship 


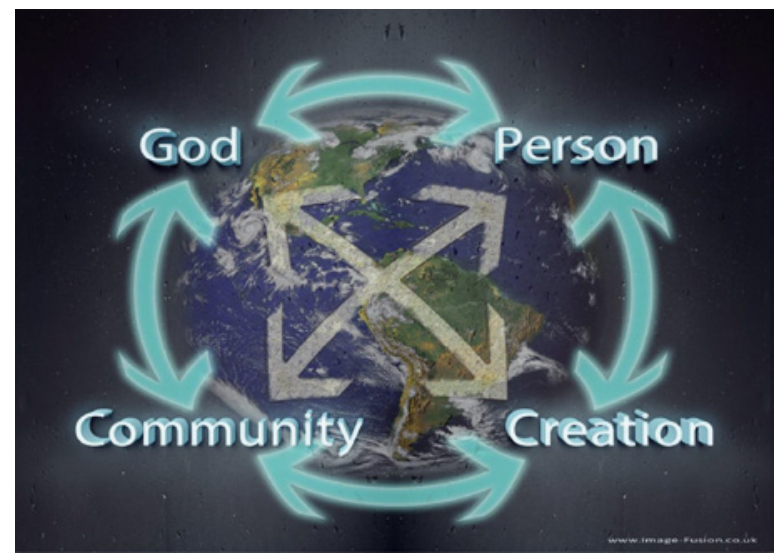

This image represents a covenantal model that includes creation as a key component in following God. To maintain a righteous and just world between God and humanity, it is necessary to include creation as well. While many covenant models include only God, community, and the individual, it is clear that creation is part of that relationship.

For their part, the Jesuits and Jesuit apostolates in the United States play an important role in this covenantal relationship. As part of their commitment to building a more just world, the Society of Jesus in the United States has begun responding to the call of Laudato si'. This essay analyzes how the us Jesuits have worked in a healing capacity in an ecological manner, as well as the shortcomings of conference as a whole and its comfortable participation in injustice. To gain a fuller understanding of the Jesuit efforts, one must look to their apostolic work. In the United States, the Society of Jesus sponsors twentyeight institutions of higher education, sixty-one secondary schools, seventeen middle schools, sixty-six parishes, and twenty-five retreat centers. This article describes and evaluates the American Jesuits' efforts both prior to and in response to Pope Francis's call for an integral ecology, focusing primarily on the institution of secondary and higher education. It is composed of two main sections: first, it briefly examines the work of individual Jesuits and provinces, before bringing focus to the efforts of secondary schools, and then colleges and universities - the latter of which receives greater attention on account of their fiscal, political, cultural, and educational power; second, this essay evaluates the Jesuits' shortcomings and participation in systems of injustice. Finally, it makes recommendations for individual Jesuits, apostolates, and provinces, particularly an integral ecology examen, to help the Society of Jesus move from this complicity to hope-filled missionary vigor.

with God in their care for each other and creation. See the accompanying image on the covenant between God, person, community, and creation. 
Two main sections compose this essay: a description of efforts both preceding and responding to Laudato si'; and a discussion of the shortcomings of the Jesuits and their institutions with suggestions for Jesuits and their apostolates to pursue integral ecology. In the first part, this essay breaks down the responses of Jesuits and Jesuit works.

\section{The Response to Laudato si'}

In 1973, Superior General Pedro Arrupe, S.J. (1907-91) offered his "Men for Others" speech to the Congress of European Jesuit Alumni in Valencia, Spain. ${ }^{6}$ His speech helped solidify and give vocabulary to growing social concerns. In the United States, the Jesuits had for many years been thoroughly involved in social apostolates, primarily concerned with labor and racial justice. "Men for Others" legitimated a sense of dedication to all of the poor and oppressed, a sense of justice that continues to inform and form Jesuits today. ${ }^{7}$ It can be seen especially in the efforts by provinces and the United States Jesuit Conference (US-JC) to battle the structural injustices that lead to environmental degradation. American Jesuit provinces and the Us-JC made strides in combatting structural environmental injustice. While these strides are taking different forms, this article will expand upon four of those: preaching, lobbying, socially responsible investing (SRI), and education.

First, following the release of Laudato si', Jesuits across the United States preached about the importance of taking steps to mitigate environmental damage. ${ }^{8}$ Though a small step, it brought the relationship between faith and

6 "Men for Others," accessed June 17, 2016, http://onlineministries.creighton.edu/Collabora tiveMinistry/men-for-others.html.

7 Commonly referred to as the "Men for Others" speech, Pedro Arrupe delivered his address, "The Promotion of Justice and the Formation in the Alumni Associations," in Spanish, to the 1oth International Congress of Jesuit Alumni of Europe, Valencia, Spain, July 31, 1973. For an English version of the speech that is edited and abridged, see Horacio de la Costa, S.J., Men for Others: Education for Social Justice and Social Action Today (Washington, DC: Jesuit Secondary Education Association, 1974). There are two versions of the original speech in Spanish, which Arrupe was not able to deliver because of the time constraints. For the longer, written version, see "Hombres para los demás: La promoción de la justitia y la formación en las asociaciones," in Hombres para los demás: Documentos dirigidos a los antiguos alumnos de la Compañía de Jesús, ed. Josep Maria Torelló, 2nd ed. (Barcelona: Asociaciones de Antiguos Alumnos de Caspe y Sarrià, 1987), http://www.sjweb.info/documents/education/ arr_men_sp.pdf (accessed June 10, 2016).

8 This preaching took the form of both homilies, as well as a great deal of writing that came out immediately following the release. See The Jesuit Post and America Magazine for many of these pieces. 
environmental justice to the forefront of pastoral concern. While many recognize the Jesuits in the United States as primarily involved in education, the Jesuits reach a wide audience also via their parishes and pastoral work. Jesuit parishes use Mass, Christian Life Communities, parish lectures, and group discussions to incorporate Laudato si' into parish life. ${ }^{9}$

Second, US-JC in its commitment to a faith that does justice is lobbying the United States Congress for greater social concern and equitability, particularly in the following issues: public health and armed conflict in Africa; human rights and forced migration in Latin America; domestic poverty; and comprehensive immigration reform. ${ }^{10}$ The US-JC drew the connections between care for creation and their existing concerns prior to Laudato si'. The encyclical, however, bolstered efforts to focus on care for creation. Pope Francis articulated the connections between environmental injustice, conflict, immigration, and poverty in Laudato si'. The US-JC's lobbying efforts reflect these connections. Following Pope Francis's historic address to Congress, the Us-JC sponsored a petition that advocated for environmental action and that supported increased funding to the Green Climate Fund, a binding treaty at the Paris climate talks, and a reduction in greenhouse gas emissions. ${ }^{11}$ Such efforts demonstrate a commitment to integral ecology.

In addition to public lobbying, the United States Jesuit Conference works for integral ecology through SRI, an investment strategy that can give shareholders a role as a socially-conscience voice in major corporations. For instance, the US-JC sponsors the National Jesuit Committee on Investment Responsibility (NJCIR), which meets regularly to advocate for "corporate behavior consistent with Catholic social teaching, through dialogues with corporations, shareholder resolutions, and proxy voting." ${ }^{2}$ While each of the American provinces participates in these efforts as well, in 2014, the committee began to focus its work on water conservation and ensuring protection of human rights in privately-run prisons. Speaking specifically on the issue of water, John Sealey

$9 \quad$ “Jesuit Institutions Rise to Pope Francis's Challenge of Laudato si," Ignatian Solidarity Network, June 14, 2016, http://ignatiansolidarity.net/blog/2016/o6/14/jesuit-pope-francis -laudato-si-encyclical-1-year/.

10 For an overview, see The Society of Jesus in Canada and the United States, "Social Justice," http://jesuits.org/socialjustice?PAGE=DTN-20150722030041 (accessed June 10, 2016).

11 Jesuit Conference National Advocacy Office, "Stand with Pope Francis on Environmental Justice," The Society of Jesus in Canada and the United States, http://cqrcengage.com/ jesuit/app/take-action?engagementId=132192 (accessed June 10, 2016).

12 National Jesuit Committee on Investment Responsibility, "National Jesuit Committee on Investment Responsibility: 2014 Review," January 7, 2015, 1, http://jesuits.org/Assets/Publi cations/File/NJCIR_14_web-v2.pdf (accessed June 10, 2016). 
(b.1961) stated that "human rights dialogues often have a prominent ecological dimension." ${ }^{13}$ The NJCIR focused in part on Bungee Limited, an agricultural corporation, because industrial agriculture utilizes and pollutes an immense amount of water. Consequently, the NJCIR and their partners urged Bungee to adopt water-sensitive measures that include overall reduction in water use, pollution/chemical runoff control, and developing water stewardship programs. ${ }^{14}$

The individual provinces also work in SRI. In the United Central Southern Province (UCS), for example, social ministries director Mary Brandon worked with Ingredion to address water scarcity and inequality. In response, Ingredion committed to water sustainability throughout its entire supply chain..$^{15}$ These public and private lobbying efforts demonstrate a commitment to an integral ecology. While several of these projects existed prior to Laudato si', the encyclical lends greater weight and legitimacy to strengthening these works.

In addition to direct lobbying efforts, Jesuits and their lay colleagues are in the process of training future generations of Catholic activists. ${ }^{16}$ In recent years, ISN and IFTJ emphasized the need for care of creation. Students spend the first days of the IFTJ learning about various issues, such as hydraulic fracturing, bottled water, and mountaintop removal mining. After learning, many students participate in an advocacy day. They meet with Congress to lobby on questions of ecology, immigration, and poverty. ${ }^{17}$ This year, over twelve hundred students lobbied for action on climate change. ${ }^{18}$ Along with sponsorship

13 Ibid., 5 .

14 Ibid., 6.

15 Ibid., 7. Ingredion is an "ingredients solutions company" that works primarily in agricultural processing for foods, drinks, and pharmaceuticals.

16 Following the Us-sponsored assassination of six El Salvadoran Jesuits, their housekeeper, and her daughter, the American Jesuit community established the Ignatian Family TeachIn for Justice (IFTJ). The teach-in began meeting annually to protest United States' involvement in Latin America, specifically police and military training. These efforts quickly grew into related social justice concerns, and so the IFTJ eventually led to the creation of the Ignatian Solidarity Network (ISN). ISN continues to host IFTJ, the largest annual Catholic social justice conference in the United States. This year's conference drew over seventeen hundred participants. Ignatian Solidarity Network, "About the Ignatian Solidarity Network," http://ignatiansolidarity.net/about/ (accessed June 10, 2016).

17 Ignatian Solidarity Network, "Ignatian Family Teach-In for Justice [IFTH] 2012 Recap," last modified December 15, 2012, http://ignatiansolidarity.net/iftj-2/ (accessed June 10, 2016).

18 "Over 1,200 to Ask Congress to Stand with Pope Francis at 18th Ignatian Family TeachIn for Justice," Ignatian Solidarity Network, last modified October 29, 2015, http:// ignatiansolidarity.net/blog/2015/10/29/over-1200-to-ask-congress-to-stand-with-pope -francis-at-18th-ignatian-family-teach-in-for-justice/ (accessed June 10, 2016). 
by the provinces and the Us-JC, many individual Jesuits do participate in and support this annual gathering. After IFTJ, ISN provides follow-up materials and programs for students to continue deepening their commitment to justice and integral ecology. These various lobbying, training, and education efforts demonstrate the commitment of individual Jesuits, the provinces, and the Us-JC to respond to Pope Francis's call for a renewed covenant.

In addition to national lobbying and education work, Laudato si' fortified local ecological efforts. With sixty-one total institutions, secondary schools represent one of the largest Jesuit ministries in the United States. ${ }^{19}$ Many of the secondary schools play prominent roles in the community. This position makes the schools an engine for creating positive local change. In their 2014 annual report, the Jesuit Secondary Education Association included questions on green initiatives, showing disparate responses to ecological justice. ${ }^{20}$ A later report was completed prior to the release of Laudato si. ${ }^{21}$ Given the starkly different responses, one can hope the encyclical may spark the ecologically-insufficient schools to catch up in their efforts. The majority of schools reported that they have instituted recycling programs-though some schools demonstrated a far deeper commitment. ${ }^{22}$ For example, Jesuit High School, New Orleans, moved beyond regular waste recycling into a computer and electronics recycling program. Rockhurst High School in Kansas City, Missouri, developed a compositing program for food waste. ${ }^{23}$ This section briefly examines secondary school efforts to integrate faith and ecological justice, demonstrating the possibilities other institutions might pursue in response to Laudato si'.

Two schools particularly stood out for their efforts to support an integral ecology: St. Louis University High School (SLUH) and Regis Jesuit High School. Under the guidance of teacher Bill Anderson, SLUH greatly increased its ecological practices in the last ten years, including programs such as: comprehensive recycling and composting; campus garden and farm; carbon reduction;

19 This number will increase in the next five years with the addition of several new Cristo Rey schools.

20 The Jesuit Secondary Education Association is now the Jesuit Schools Network. The survey, however, was completed under the previous name.

21 By this point, the organization had changed names to Jesuit Schools Network, reflecting the increasing number of middle schools part of the organization.

22 "Jesuit Secondary Education Association Annual Report," Green Initiatives Information (Washington, DC: Jesuit Secondary Education Association, September 2014). Ibid. 
solar panel installation; and waste reduction. ${ }^{24}$ These efforts have not come easily. SLUH confronted the dual challenges of education and behavioral change. Composting efforts, for instance, reflected these challenges. The introduction of food waste composting forced students to change their understanding and behaviors surrounding waste management for sake of the common good. ${ }^{25}$ In addition to composting, SLUH articulated several other ecological goals. For instance, SLUH has set an objective of seven recycling pick-ups to every trash pick-up. ${ }^{26}$ The school also instituted regular energy audits, while seeking ways of reducing total energy use, and it aims to utilize sustainable and local food sources, decrease water runoff and waste, and reduce waste related to new construction and renovation. ${ }^{27}$ These goals demonstrate a thoughtful and considerate approach to ecology that not only supports the school, but benefits the surrounding community.

Like SLU H, Regis Jesuit in Denver pursues efforts to mitigate their ecological footprint. Perhaps most telling, the landing page of Regis's website has a direct link to their extensive sustainability efforts. The school states, "Regis Jesuit High School seeks to integrate sustainability processes and a deep respect for the natural world into every facet of the institution. The school and the next generation of students must internalize their responsibilities for living sustainable and restorative lives." ${ }^{28}$ Regis outlines a substantial list of their conservation efforts that includes electricity reduction, energy tracking, physical waste reduction, eco-friendly landscaping, and water reduction. These projects demonstrate real and tangible efforts that respond to both the local and global environmental concerns.

As JSN vice president Bill Hobbs (b.1963) noted, many of these efforts began prior to Laudato si' - and the network has not collected data since the release of the encyclical. In April 2016, JSN hosted a national meeting for its service directors. Hobbs—as he stated at the time of this interview—expects

24 St. Louis University High School, “SLUH Going Green," http://www.sluh.org/news/article/ 2325/ (accessed June 10, 2016).

25 Connor Fitzgerald, "Commentary: A Call to Careful Stewardship," Prep News, November 6, 2015, http://student.sluh.org/prepnews/index.php/archives2/item/420-commentary (accessed June 10, 2016).

26 In other words, this means that SLUH would collect seven times as much recycling as it does garbage.

27 St. Louis University High School, "sluh Sustainability," St. Louis University High School, http://www.sluh.org/about/sustainability/ (accessed June 10, 2016).

28 Regis Jesuit High School (Denver), "About Us - Facilities - Sustain," https://www.regisje suit.com/about-us---facilities---sustain (accessed June 10, 2016). 
sustainability and Laudato si' to be major themes at the meeting. ${ }^{29}$ Despite this delay, many of the Jesuit high schools in the United States already demonstrated a keen interest in environmental concern. This prior concern bears hope. With schools like SLUH and Regis paving the way, one must hope that other JSN schools use Laudato si' as impetus for further action.

In addition to the numerous secondary schools, the Jesuits sponsor twentyeight colleges and universities in the United States. These colleges collaborate through the Association of Jesuit Colleges and Universities (AJCU). Jesuit higher education in the United States ranges from international research universities to those that primarily serve regional populations. With nationally ranked academics, a powerful moral voice, and a collective endowment of over eleven billion dollars, Jesuit colleges and universities find themselves amply placed for creating positive change in the world. ${ }^{30}$ Most of the twenty-eight colleges had already begun making these changes prior to Laudato si. ${ }^{31}$ This section details the work of four universities seeking to improve the natural world, providing a model for other colleges to integrate ecological concern into their mission.

At College of the Holy Cross, for instance, there is an effort to make sustainability a core concern across campus, initiating this commitment from the ground up. A group of faculty voiced their concern for environmental stewardship. Since then, Holy Cross increased its dedication to sustainability. The engagement spread from the core group of faculty to a group of faculty, staff, and students involved in almost every aspect of the college. This engagement included ample support from President Philip Boroughs, S.J. (b.1949), and the administration.

Perhaps more importantly, as Sustainability Taskforce co-chair Kathy Kiel (b.196o) notes, it was the entry of sustainability into everyday language. Ecological efforts do not reside with one committee, organization, or individual. Rather, the entire university undertook sustainability as a vital part of the mission. ${ }^{32}$ Kiel commented on the special pride that Holy Cross feels for several of its accomplishments. In 2007, Holy Cross signed the American College and University Presidents Climate Commitment (ACUPCC). As part of this commitment, Holy Cross aims to be carbon neutral by 2040,33 and already achieved

\footnotetext{
29 Bill Hobbs, "Green Initiatives at JSN Schools," August 4, 2015.

$30 \quad$ Endowment data collected from U.s. News and World Report.

31 Of the twenty-eight schools, twelve replied with information. Many of the others have environmental protection and stewardship information readily available on their websites.

32 Kathy Kiel (University of the Holy Cross), discussion with the author via telephone, August 12, 2015.

33 College of the Holy Cross, "Sustainability," http://www.holycross.edu/campus-life/sus tainability (accessed June 10, 2016).
} 
a forty percent reduction in their carbon footprint. ${ }^{34}$ This success, according to Kiel, came from a unified approach. While the division of buildings and grounds worked on insulation and reducing energy loss, dining services simultaneously started utilizing local food sources in order to cut down on shippingrelated carbon. Landscaping began composting grounds materials and saw an immediate reduction in both waste and excess fertilizers. In terms of curricular development, Holy Cross strengthened its environmental studies major, in which students focus research on policy, economics, and community action. ${ }^{35}$

Indeed, many of Holy Cross's projects preceded Laudato si', yet this initiative was augmented with the release of the encyclical for a greater response. The environmental studies major and Eco-Action club planned several events as a response to Laudato si, including study groups, a broadcast of Pope Francis's speech to the us Congress, and an interdisciplinary panel of experts for a thorough conversation about the hopes and challenges brought forward by Pope Francis. ${ }^{36}$ Kiel highlights the importance of an interdisciplinary approach, saying that Pope Francis correctly links poverty, environmental degradation, and the need for the common good. ${ }^{37}$

The encyclical played a critical role, according to Kiel, in its timing. As Holy Cross, for example, moves forward in its greening efforts, greater challenges loom. The college already, Kiel states, "picked much of the low-hanging fruit," and the greatest reductions, mobilizations, and collaborations still await. Kiel appreciates the simultaneous challenge and hope presented in Laudato si'. ${ }^{38}$ Pope Francis gave the college community both a sense of capability and culpability. Holy Cross possesses the tools and responsibility to take action. Given Pope Francis's encouragement, Kiel believes that Holy Cross will continue moving toward an integral ecology.

Similar to College of the Holy Cross, St. Louis University's environmental stewardship programs began as a grassroots initiative. Six years ago, the Division of Facilities Services at St. Louis University (SLU) created a strategic plan that included Environmental Resource Optimization Action Teams (ERO). ${ }^{39}$

\footnotetext{
34 Kiel, discussion with the author.

35 Ibid.

36 College of the Holy Cross, "Pope Francis on the Globalization of Environmental Responsibility: Perspectives of Holy Cross Faculty," http://www.holycross.edu/faith-service/ mcfarland-center-religion-ethics-and-culture/pope-francis-globalization-environmen tal-responsibility (accessed June 10, 2016).

37 Kiel, discussion with the author.

38 Ibid.

39 Brandon Verhoff (Saint Louis University) in discussion with the author via phone, August 13, 2015.
} 
Facilities hoped to bring greater awareness and action to care for creation. Teams formed in three categories: integration, initiative, and awareness. ${ }^{40}$ Briefly thereafter, the Alberici Foundation gave a five-million-dollar grant to the SLU and their Center for Sustainability. ${ }^{41}$

SLU director of sustainability and benchmarking Brandon Verhoff (b.1982) spoke of SLU's integrative approach to sustainability. This approach includes climate change, waste management, natural resource management, common good, and recognizing the relationship of poverty and environmental degradation. SLU set forward multiple goals in each of these areas. In waste management, the university currently diverts fifteen to twenty-eight percent of waste from landfill. They aim to divert over thirty percent. Facilities management developed a multi-step approach, including education about what can be recycled, as well as expanding the university's ability to recycle a greater number of items. Recently, SLU added electronic recycling and food composting. ${ }^{42}$ SLU also completed its first comprehensive greenhouse gas inventory, which examined carbon emissions from lawnmowers to the carbon from purchased goods. The inventory will help Verhoff and the university to further establish clearer goals and expectations. To offset carbon emissions, SLU recently installed nine solar arrays that remove 191 metric tons of carbon dioxide, or the equivalent of about seventeen American homes. ${ }^{43}$

While the administration leads many of the initiatives, the student body takes a prominent role in moving the university toward greater stewardship. Thanks to student-led advocacy, the university - in addition to installing water bottle filling stations - gives a reusable bottle to every incoming first year student, and is removing disposable bottles from campus. Students examined issues beyond just the waste associated with plastic bottles, noting that water privatization seeks control over a basic human right. ${ }^{44}$ Not only does this damage the environment, but privatization dramatically affects the poor and marginalized. Privatization frequently increases the cost of water and makes it inaccessible to the poor. Moreover, the poor are left with the waste and refuse. Verhoff noted that students regularly examine sustainability not as a standalone environmental issue, but as a comprehensive social justice problem. ${ }^{45}$

40 Saint Louis University, "SLustainability Groups: Get Involved," http://www.slu.edu/ facilities-services-home/sustainability/groups?site=mobile (accessed June 10, 2016).

41 Verhoff interview.

42 Ibid.

43 Ibid.

44 Brandon Verhoff, "Saint Louis University staRs Report" (St. Louis, MO: Saint Louis University, February 26, 2015), 49.

45 Verhoff interview. 
Collaboration between faculty, staff, and students will prove vital as SLU continues to pursue an integral ecology. The university already established goals for reducing water and energy use, aiming to cut back by twenty percent before 2020. Although the university progressed more slowly on energy, concerning water they have already met their reduction goals. Having recently completed the comprehensive carbon audit, the SLU community must now establish an equally comprehensive plan for reducing emissions. As with issues like bottled water, Verhoff commented that SLU desires its goals to reflect not only the aims of environmental justice, but communal justice and human dignity as well. SLU utilizes benchmarks common to other universities, such as the STARS program and Tree Campus USA. Their efforts, however, reflect a strong sense of Catholic social teaching and cura personalis. Verhoff hopes that Pope Francis's mission-oriented approach to the environment will help further integrate the university, drawing in Campus Ministry, Theology, and other departments. ${ }^{46}$ This hope emanates from the legitimizing power of Laudato si' and the immense work yet to be done by Jesuit institutions.

Like College of the Holy Cross and St. Louis University, ecological concern at Loyola University New Orleans (LUNO) emerged from faculty and student activism. Whereas Holy Cross and SLU are nationally-recognized and relatively well-endowed universities, LUNO is a smaller regional school. Their story represents equally important action, but with a smaller budget and great focus on smaller steps. In the 1980s, the faculty recognized gaps in their efforts for social justice. While Luno had a strong minor in environmental studies, many questions and areas of study sat untouched. In response, Bob Thomas decided to teach the course "Environmental Analysis of Loyola University," which enabled students to research various ecological ills in which the university participated. As a result, student research revealed that the division of buildings and grounds had developed an eco-friendly approach not expressly for the sake of the earth, but simply because it was less expensive. ${ }^{47}$

Since that initial student research project, LUNO progressed toward greater environmental stewardship and human equity, and despite limited funding, students and faculty remained dedicated with a grassroots effort focused on attainable goals. Currently, for instance, the campus is collectively focusing on eliminating bottled water. As part of this project, the sustainability group received funding to install water filling stations on campus. Within a year of

\footnotetext{
46 Ibid.

47 Bob Thomas (Loyola University New Orleans) in discussion with the author via phone, August 10, 2015.
} 
installation, students used the filling stations over one hundred thousand times. These efforts to ban bottled water brought to the forefront access to clean drinking water as an issue of social justice. While students on campus may enjoy bottled water for as much as eleven dollars per gallon, others in New Orleans struggle to afford this most basic of human rights. ${ }^{48}$

From Thomas's perspective, Laudato si' might help the LUNO strive for greater integration of environmental stewardship, care for the poor, and student learning. Perhaps of equal importance, the encyclical might help the university community to reflect and recognize the excellent work it already accomplished. LUNO implemented fiscally practical and environmentally sustainable solutions. Thomas hopes Laudato si' will simultaneously highlight the importance of such measures, as well as create the momentum necessary for further steps. Prospectively, a greenhouse gas audit remains a viable next step for the university. Creating a culture of caring for creation, Thomas states, is clearly a vital part of Jesuit, Catholic identity and mission. ${ }^{49}$ A deeper examination of Ignatian identity and school values may lead to the integral ecology of Pope Francis.

While grassroots efforts sustain the ecological efforts at many universities, one individual in a leadership position can often be a catalyst for change. Karen Price (b.1958) held the position of sustainability manager at Seattle University for nine years. Under her direction, green building and campus sustainability became major foci of the entire campus. Price created a university policy that mandated all new buildings to meet the standards for LEED Gold certification. ${ }^{50}$ Her work paved the way for institutional considerations of ecology..$^{51}$ Due to Price's leadership, Seattle University not only continued its mission in this regard, but also sought the magis in creating a more just and sustainable campus.

Phil Thompson, director of the Center for Environmental Justice and Sustainability at Seattle University, states that the university effectively became a model and leader in environmental stewardship, and that their ecological efforts reach every facet of campus life. Ecologically-friendly buildings remain the most obvious greening effort on campus. Seattle University presently has four LEED Gold buildings, as well as retrofitting older buildings to be more

\footnotetext{
48 Ibid.

49 Ibid.

5O LEED is a certification program run by the U.s. Green Building Council, and is a standard measure with four levels of achievement: certified, silver, gold, and platinum.

$5^{1}$ Phil Thompson (Seattle University), discussion with the author via telephone, August 10, 2015.
} 
efficient. ${ }^{52}$ Along with its buildings, Seattle University generated a great deal of ecological integration in other areas. For example, hydroelectricity powers the entire campus vehicle fleet. Moreover, when faculty or staff travels for school-related purposes, Seattle University is proposing carbon offsets. Seattle University also helped set the precedent for campus composting. At ten years old, the university composting program boasts incredibly fertile and productive compost. ${ }^{53}$

In the classroom, Seattle University offers a plethora of environmentrelated courses. The university delivers three undergraduate programs in sustainability, as well as several graduate specializations. Seattle University provides over fifty courses specifically geared toward environmental stewardship. Recognizing the complex relationship between the environment and justice, many of these courses have multiple foci. For example, one might take "Housing Design and the Sustainable Community" or "Sustainable Sport Facility Management." ${ }^{n 4}$ Ecological justice has become a required facet of education at Seattle University, and thus every student must consider his or her impact on the natural world..$^{55}$

The release of Laudato si' furthered campus efforts for integral ecology. Every year, the Institute for Catholic Thought and Culture offers the Heritage Lecture Series. In the 2015-16 school year, the Institute will focus on nature and theology in the series "Care for the Earth, Care for the Poor." Speakers in this series include Ilia Delia, O.S.F., Christiana Peppard, and Jose Ramon Villarin, S.J. ${ }^{56}$ Thompson expressed his desire to see the university further integrate theology, ministry, the social sciences, and environmental concern, proclaiming that Laudato si' may be the catalyst necessary to reinvigorate concern around environmental stewardship and social justice. For example, student and faculty fellows began examining projects around sustainable and affordable lowincome housing. Thompson hopes these fellowships and the encyclical can help students develop programs around safe drinking water for the poor and

$5^{2}$ Center for Environmental Justice and Sustainability, Seattle University, "What su Is Doing - Buildings," www.seattleu.edu/cejs/sustainability/what-su-is-doing/buildings/ (accessed June 10, 2016).

53 Thompson, discussion with the author.

54 Center for Environmental Justice and Sustainability, Seattle University, "Courses," accessed November 29, 2015, http://www.seattleu.edu/cejs/for-students/courses (accessed June 10, 2016).

55 Thompson, discussion with the author.

56 Catholic Heritage Lectures, Institute for Catholic Thought and Culture, Seattle University, "Upcoming Speakers," https://www.seattleu.edu/ictc/events/catholic-heritage-lectures/ (accessed June 10, 2016). 
combatting homelessness. Thompson ultimately believes that Laudato si' will bring about more projects correlating creation and poverty. ${ }^{57}$

Broader environmental agenda is already becoming part of the mission of the Jesuits and their apostolic endeavors in the wider community. The provinces and the us Jesuit conference worked together through lobbying both public officials and individual corporations. Province-sponsored organizations like ISN provide education and training. High schools started to engage environmental concern, while Jesuit colleges and universities use their power in research and learning to draw students and the community into stewardship and care for creation. ${ }^{58}$ Although many of these efforts began prior to the release of Laudato si', it is vital that these institutions use the encyclical to drive further ecological integration and covenantal care of creation.

\section{The Need for New Direction}

Although Jesuits and their apostolic works have begun responding to the modern environmental crisis, it is apparent that much work remains to be done. The challenges ahead, however, loom all the greater because they stand to confront comfort and the status quo. Many of the actions that Jesuits have thus far taken are the kinds of steps that come rather easily. The Society of Jesus must now address its ecological culpability in order to bring about ecological conversion. This part examines important next steps and subsequently recommends action to more fully respond to the demands of an integral ecology and service to the poor.

In a similar manner, American Jesuit secondary schools must undergo an ecological conversion. While schools like SLUH and Regis support greening efforts, there are still many that remain stagnant. Seventeen of the schools reported no current green initiatives. Another thirty-three schools stated that they are not currently implementing any new green initiatives. ${ }^{59}$ Yet Jesuit secondary schools in the United States subscribe to the Grad at Grad values model, which states that by graduation, a student of a Jesuit secondary school

\footnotetext{
57 Thompson, discussion with the author.

$5^{8}$ There was insufficient room to highlight all of their excellent work, but the following institutions must receive recognition for their helpful response to this essay and dedication to the environment: University of Scranton, Xavier University, Loyola University Chicago, Gonzaga University, Creighton University, Fordham University, Santa Clara University, and John Carroll University.

59 Hobbs, "Green Initiatives at JSN Schools."
} 
"practices a sustainable lifestyle based on awareness of social, economic and environmental consequences." ${ }^{0}$ Furthermore, according to this model profile, such a student "is working to be environmentally responsible by limiting the use of non-renewable resources and maximizing sustainable resources." ${ }^{61}$ American Jesuit secondary schools once provided space for organizing movements and challenging the status quo. ${ }^{62}$ The number of green initiatives at Jesuit schools do not represent Catholic or Jesuit values. They should now take the steps necessary to achieve ecological conversion in the schools and students. The high schools need to model ecological integrity to their students. With the Grad at Grad values, Jesuit secondary schools named the ecological conversion, thus challenging their own comfort and power in the name of God and a more just world.

Although the Jesuit colleges and universities have done the most work of any of the communities and apostolates, challenges and opportunities lie ahead. Dave Lococo (b.1948), executive director of physical plant and sustainability at Xavier University, expressed hope that Laudato si'would impact every aspect of university life, helping the college live in right relationship with the community, creation, and God. ${ }^{63}$ Nancy Bertaux, a professor of economics at Xavier, added that the encyclical enables leadership. ${ }^{64}$ The colleges themselves as well as the AJCU must now show tremendous leadership that reflects the values of Laudato si'. Xavier University, for example, experienced a growth spurt in recent years, leading it to exhaust its ability to borrow. ${ }^{65}$ With choices of how to spend endowment, Jesuit universities frequently compromise ecological projects. ${ }^{66}$ The universities, rooted in their Jesuit identity, should reflect poverty and spiritual indifference, yet several of the interviewees for this article spoke of the difficulty of cost and long-term viability. As Jesuit universities

6o Jesuit Schools Network, "Profile of the Graduate at Graduation," revised August 14, 2015, 7, http://www.jesuitschoolsnetwork.org/sites/default/files/pages/Profile\%2oof\%2othe\% 20Graduate\%20at\%20Graduation\%202010\%20-\%2oRevised\%208.14.2015.pdf (accessed June 10, 2016).

61 Ibid.

62 Daniel Lord, S.J., "Catholic Action School: Second Year," America Magazine 47, no. 11 (1932): 253 .

63 Nancy Bertaux and Dave Lococo (Xavier University), discussions with the author, October 27,2015 .

64 Ibid.

65 Ibid.

66 Thompson, discussion with the author, in which Thompson commented that Seattle University and other universities typically cut ecological programs first. 
must practice greater discernment on integral ecology, so too on urgent fiscal questions: Should endowments be spent on developing a new environmental justice major? Or should schools spend on the more fiscally lucrative business school project? An environmental assessment should accompany most if not all major decisions a university undertakes. As such, they must prioritize an integral ecology and response to Laudato si'.

Jesuit colleges and universities aim to transform their students for the common good. They must pursue this transformative goal for higher education as well. Higher education in the United States became game of wealth and power. The Society of Jesus can change this paradigm. Trends of low pay, environmental degradation, overemphasis on athletics, and using education as a tool for dominance pervade higher education. These sins lurk inside Jesuit schools. Jesuit schools have the opportunity to throw off desire for power in exchange for the common good and preferential option for the poor.

Pope Francis and Laudato si' brought the American Jesuit community to an abrupt crossroad. In a sense, Jesuit communities and institutions are committed to the gradual adjustment of unjust systems - they aspire toward justice, yet comfortably participate in those same injustices they seek to overcome. Jesuit schools question and challenge injustice and encourage new ways of thinking. Jesuit communities speak fervently for justice rooted in God's covenantal love. Yet, in true Jesuit fashion, Laudato si' demands magis. Pope Francis spoke of deeper self-evaluation, critical consideration, and a movement toward a brighter hope, mercy, and justice. ${ }^{67}$

By and large, individual Jesuits in the United States willingly change "the little things" to make for a better environment. Many participate in activism. Others switch to shorter showers, become vegetarians, or try to use public transit. These small actions are good first steps. Unfortunately, these steps represent the stopping point for many Jesuits and Jesuit communities. Small efforts represent a disparate and individualized approach to tackling environmental concern. ${ }^{68}$ Should American Jesuits desire to address Laudato si', they must undertake a more unified and comprehensive change in lifestyle. ${ }^{69} \mathrm{An}$ analogy might demonstrate this point. A great storm approached, promising to swallow the city in a flood unless volunteers built a sandbag levee. Many volunteers arrived and built the levee, but each focused on the small portion they could accomplish. They did not work together. When the storm arrived, gaps in the

\footnotetext{
67 Francis, Laudato si', n. 205.

68 Ibid., n. 219.

69 Francis, Evangelii gaudium, n. 180.
} 
levee allowed waters to rush in and drown the city. American Jesuits implicitly presently operate under this model. They require leadership and a framework for communally changing lifestyles and habits.

In Laudato si', Pope Francis recognized the absolute connection between environmental degradation and poverty. Environmental catastrophe overwhelmingly affects the poor and marginalized. ${ }^{70}$ Some American Jesuits take their vow of poverty seriously as individuals, while other individuals treat it as a mere aside. The same can be said of communal Jesuit poverty. The majority of American Jesuits live in relative comfort, while many live in outright luxury. Yet, as Jerónimo Nadal (1507-80) recounts, Ignatius spoke of the conversational method of "entering by their door so as to come out by our door."71 By that Nadal intends to illustrate the technique in guiding a conversation, for instance, about politics to one of the life of Christ. Indeed, the Jesuits utilized this methodology for centuries, but in the United States particularly, we are not firm enough about envisioning and using our exit. We tend to enter through the door of wealth and power, politely discussing justice, and then frequently and comfortably leave through that same door of wealth and power. Individual Jesuits and communities need to closely examine these habits.

One Ignatian practice that is a basic part of the Jesuit repertoire that may prove fruitful, both personally and as a community, is a sort of ecological examen..$^{72}$ Several questions might guide this examen. Do we accrue wealth for comfort or to remain apostolically viable? Are our communities comfortable to provide a place to physically and spiritually recharge or are they places of luxury and disconnect from the poor? Do our lifestyles make us available or sedentary? Does our lifestyle witness to affluence or witness to the Gospel? Does our lifestyle lead to our individual and communal liberation or further tie us to material comfort and wealth? While addressing these kinds of questions, it would be prudent to avoid easy responses as a matter of ecological laziness, as Pope Francis warns in Laudato si:

\footnotetext{
$70 \quad$ Francis, Laudato si', n. 16.

71 For this account by Jerómino Nadal, see "From Any Other Ministrations Whatsoever of the Word of God' in The Conversational Word of God," in The Ignatian Tradition, ed. Kevin F. Burke and Eileen Burke-Sullivan (Collegeville, MN: Liturgical Press, 2009), 31.

As of the writing of this article, the Us-Jc had not undertaken a comprehensive examination of its environmental impact. It would be a worthwhile endeavor for the American Jesuits to complete at least a moderate ecological inventory or carbon footprint. From there, they might set standards or guidelines that might enhance vows of poverty and apostolic availability. It would also give a specific framework around which to host an ecological examen.
} 
They choose not to change their habits and thus become inconsistent. So what they all need is an "ecological conversion," whereby the effects of their encounter with Jesus Christ become evident in their relationship with the world around them. Living our vocation to be protectors of God's handiwork is essential to a life of virtue. ${ }^{73}$

It is apparent that the American Society of Jesus desperately needs to open itself to an ecological conversion. It must turn to its roots in the Spiritual Exercises and listen for God's movements. Through these tools, the American Jesuits will challenge not only their own comfort, but the comfort of those whom they serve as well.

\section{Conclusion}

In Laudato si', Pope Francis quotes the Earth Charter, stating, "As never before in history, common destiny beckons us to seek a new beginning." ${ }^{\prime 4}$ For Jesuits, the road ahead is clear in one respect - the Society must break free of the unjust structures to which it has become bound, allowing them free to fully preach the Good News to the poor and oppressed. At present, this Good News entails pursuing an integral ecology that recognizes the covenantal nature of serving the poor and protecting creation.

The Jesuits and their apostolic institutions in the United States have built a forceful tradition of speaking for the least of our sisters and brothers. In light of Laudato si', they have both the opportunity and vocational mandate to redouble those efforts. The Jesuits find themselves bound to wealth, comfort, and power. Gradually transforming this present system of injustice reached its limit. To liberate God's people from injustice and build an integral ecology, the Jesuits should seek out their own conversion, as well as the conversion of the world around them. This liberation and conversion leads to a renewal of God's covenant. The conversion will not come easily. Rather, Jesuits will have to seek conversion with vigor, intensity, and a reaffirmation of their vocation to God and the poor. ${ }^{75}$ Let us pray that God continues to inspire, create, and affirm the covenantal love which simultaneously calls us to Christ and commissions us outward to serve our sisters and brothers.

\footnotetext{
73 Francis, Laudato si', n. 217.

74 Ibid., n. 207; Earth Charter, "Read the Charter," http://www.earthcharterinaction.org/ content/pages/Read-the-Charter.html (accessed June 10, 2016).

75 Francis, Laudato si', n. 217.
} 